\title{
3 Research Square \\ Use of Chemical Signature to Trace the Impact of Emission Sources
}

\section{Angelo Cecinato ( $\square$ angelo.cecinato@iia.cnr.it )}

National Research Council of Italy https://orcid.org/0000-0002-3308-0479

Alessandro Bacaloni

Sapienza University of Rome: Universita degli Studi di Roma La Sapienza

\section{Paola Romagnoli}

IIA CNR: Istituto sull'Inquinamento Atmosferico Consiglio Nazionale delle Ricerche

\section{Mattia Perilli}

IIA CNR: Istituto sull'Inquinamento Atmosferico Consiglio Nazionale delle Ricerche

\section{Catia Balducci}

IIA CNR: Istituto sull'Inquinamento Atmosferico Consiglio Nazionale delle Ricerche

\section{Research Article}

Keywords: molecular markers, chemical signature of sources, diagnostic concentration ratios, particulate organic matter (POM), tobacco smoke, air pollution, toxicants.

Posted Date: May 17th, 2021

DOl: https://doi.org/10.21203/rs.3.rs-450504/v1

License: (c) (i) This work is licensed under a Creative Commons Attribution 4.0 International License.

Read Full License 


\section{Abstract}

The composition of organic fraction associated to particulate emissions depends on their nature as well as on contour conditions. Therefore, many Authors have investigated the chemical signature of airborne particulate matter and dusts with the goal of identifying the pollution sources and assessing their impact on the environment and health. Usually, Authors use three complementary tools for this goal; they are specific source markers, concentration ratios of pairs of congeners, and percent distributions of homologues within a group. After the presentation of the state-of-the-art about non-polar aliphatic (alkanes and alkenes), aromatic (PAHs, Nitro-PAHs) and polar (fatty acids, organic halides, polysaccharides) compounds associated to emissions, this paper provides new information with regard to chemical signature non-polar fraction, suitable to trace the impact of sources on airborne particulate matter and settled dust. Non-polar organic fraction comprises short/medium-chain alkenes and alkanes (with carbon numbers ranging from 12 to 23), which display distinct relative abundances in petrol-derived exhausts, microorganism residues and high vegetation leaf debris. Meanwhile, long-chain alkanes associated to tobacco smoke show a peculiar iso/anteiso/normal homologues fingerprint as well as $n$ hentriacontane percentages higher than other emissions. Based on this particular alkane distribution, two indexes (ATSR and AICR) have tentatively identified and tested though comparing their rates in some sets of particulate samples. Until now, the study of molecular signature has overall limited to qualitative purposes and seldom exploited to achieve quantitative estimates of contributions of sources to air pollution. Future investigations will reach this goal through further clarifying the nature and behavior of organic contaminants associated to airborne and settled particulate matters.

\section{Introduction}

The release of toxicants in the atmosphere has recognized to induce harmful effects on humans and injure the environment. Therefore, the knowledge of nature, amount and land spread of emissions appears mandatory if strategies aimed at mitigating the toxicants impact must be implemented [Albaiges et al 1984, Bascom et al 1996, Yassaa at al 2001, Ma et al 2015, Błaszczyk et al 2017, Sifakis et al 2017, Cetin et al 2018, Nieder et al 2018, Vaz 2018]. Chemical and physical characterization of gas and particulate phases plays a key role to picture the aftermaths of pollutants release into the environment (i.e., through valuing the concentrations of selected chemicals in air and exhausts and comparing them with current legislation). Besides, it allows assessing the relative importance of sources that affect the site or land domain which is under study [Gundel et al 1993, Hecht 1999, Ventrice et al 2013, Jedynska et al 2014, Giulivo et al 2016, Liu et al 2017, Praveena et al 2018, Rabhi et al 2018, Yuri et al 2018, Brehmer et al 2020].

At this regard, organic substances associated to particulate matter (both aerosols and dust settled on surfaces and soil) are important tools of investigation and at the same time subjects of scientific challenge, due to their complexity and variety. Organic substances are classified in a number of groups displaying very different properties like acidity/alkalinity/neutrality, grade of polarity, water and n-octanol solubility, vapor pressure, inertness vs. oxidants and light- They are linear and cyclic aliphatic 
compounds, polycyclic aromatic hydrocarbons, acids, amines, carbonyls, halides, organic sulfates and phosphates, etc.. Many of them, as peculiarly associated to sources, have identified as tracers of living organisms, natural phenomena and man's activities.

Unfortunately, only in a handful of happy cases one substance is unequivocally typical of one emission, so that it allows revealing and even valuing the impact of that source on the environment. More frequently, many chemicals are associated to many emissions, and the compound peculiarity is missed, nevertheless, in this case the composition per groups and the distribution pattern of congeners within organic groups can aid in the goal of identifying the pollution sources. For instance, biofuels are usually richer of esters than fossil fuels, and the opposite occurs for polycyclic aromatic hydrocarbons (PAHs) [Damanik et al 2018]. Besides, the percentages of PAHs associated to ultra-fine, fine and coarse fractions of suspended particulate change with the nature of source [Zielinska et al 2004]. Fresh exhausts are prone to action of light (overall UV) and oxidizing species $\left(\mathrm{O}_{3}, \mathrm{NO}_{2}, \mathrm{OH}\right.$ and $\mathrm{NO}_{3}$ radicals) [Arey and Atkinson 2003, Estève et al 2004, Perraudin et al 2007]. Thus, chemicals primarily released into the atmosphere are transformed into degradation products (e.g., ketones and quinones, polyacids, diols, epoxides, cumulatively defined as secondary pollutants) that modify the chemical signature of the substrate as well the toxic properties of the air parcel impacted by the exhausts [Atkinson and Arey 1994, Durant et al 1999, Bandowe et al 2014]. As for airborne particulates, this reactivity introduces some uncertainty with regard to the source identification, since wide ranges of lifetime characterize organic chemicals, on the other hand, the rate of chemical degradation can be regarded as an index of air parcel ageing, i.e. of the importance of reactions developing there [Sofowote et al 2010, Cecinato et al 2014]. Instead, in the case of dusts the impact of atmospheric reactivity is by far more important, because fine particles need time to settle on surfaces and the collection period of samples usually lasts $\geq 15$ days.

The first approaches to identify the emission sources of organic toxicants by means of molecular signatures have made in late twentieth century [Daisey et al., 1986, Harrison et al., 1996]. Focus was addressed overall to alkanes, PAHs and nitrated derivatives (NPAHs), but some investigations regarded fatty acids, halides (e.g. dioxins and furans PCDD/Fs, polychlorobiphenyls PCBs, polybromodiphenylethers PBDEs), polysaccharides (levoglucosan, mannosan), sterols (cholesterol, stigmasterol, sitosterol) and triterpenols (amyrins). Due to intrinsic limits of the simple molecular signature use, other tools have adopted preferably to trace the pollution sources impact, e.g. PCA, nevertheless, this the study of chemical fingerprints remains proper for the preliminary analysis of organic matter. Besides, molecular signature is easily integrated in statistical approaches based on a number of chemical and physical variables [Kavouras et al 2001, Mostert et al 2010, Brown and Brown 2012a/b, Khedidji et al 2017, Chen et al 2019, Maechler et al 2019, Molnar 2019, Sofowote et al 2020], which look suitable for source apportionment studies.

As for sources, interiors as a whole look as a space very different from outdoor environment. [Zhao et al 2007, Guo and Kannan 2013, Sangiorgi et al 2013, Romagnoli et al 2014, Hassanvand et al 2015, Tran et al 2015, Oliveira et al 2016, Subedi et al 2017, Liu et al 2018, Lu et al 2018, Lucattini et al 2018, Steinemann 2018, Wong et al 2019, Zhu et al 2019]. Three kinds of contaminants affect indoor locations, 
i.e.: i) chemicals overall released outdoors and moved into the interiors through building openings and ventilation devices (e.g., hydrocarbons present in motor vehicle exhausts), ii) substances released indoors and outdoors at broadly analogous levels (e.g., nitrogen oxides, psychotropic substances), and iii) compounds predominantly released by typical indoor sources (e.g., deodorants, plasticizers). Besides, chemicals released indoors meet up environmental contours heavily different from open air, e.g., temperatures are much less varying, ozone is much less and surfaces are much larger. All of them change the chemistry of interiors, the lifetime of substances and the gas/condensed phase equilibria. Although human exposure to toxicants occurs predominantly in interiors, legislation dealing with indoor pollution is still insufficient aside of workplaces, while extensive investigations concerning the air quality of interiors deal overall with tobacco smoking.

This paper provides an overview of investigations carried out by our team, aimed at identifying the molecular fingerprints of organic fraction of airborne particulate matter and deposition dust, potentially suitable to draw information about the sources of pollution and the respective impact on the environment. Three major categories of fingerprints will discussed, namely: i) individual tracers, ii) diagnostic concentration ratios, and iii) homologue percent distributions within groups.

\section{The State-of-the-art Of Research About Molecular Signatures Of Pollution Sources}

2.1. General features of emission profiles. Apart from environmental contour, three key factors influence the composition of emissions resulting from chemical analysis. They are: $i)$ the operating conditions of emission source, including the kind of fuel, temperature of exhausts, type of abatement devices, ii) the procedure of collection (which includes vapors, particles or both), and iii) the methodology adopted to process samples and determine chemical composition. These factors make hard to assign thorough emission factors to chemicals released from the sources, and to assess precise values to concentration ratios or percentages of substances considered in the molecular fingerprints [Tobiszewski and Namiesnik 2012, Cecinato et al 2014]. Investigations undertaken with different methodological approaches can lead to not comparable results. For instance, the n-alkane profile detected in organic particulate matter depends on temperature occurring during sampling, which influences the loss rates of the most volatile compounds. Therefore, the study of n-alkanes percent distribution is mostly restricted to high molecular weight homologues, namely to hydrocarbons with carbon number $\geq 25\left(\mathrm{C}_{25}\right)$. As for PAHs, compounds with similar vapor pressures and/or high molecular weights are preferred to choose the ratios of concentration to select as diagnostic of sources. Anyway, in our work the organic matter composition was determined by applying similar methodologies for all of emission exhausts, suspended particulates and dusts. The samples have first analyzed according to state-of-the-art of literature, and then chemical characterization has improved to draw further insights about the nature of sources.

2.2. n-Alkanes. Non-polar fraction of particulate organic matter POM includes numerous groups. They are alkanes, alkylated mono-aromatics and biphenyls, alkenes, branched and cyclic-aliphatic hydrocarbons. Among them, attention has paid overall to n-alkanes (linear homologues), alicyclic compounds have 
investigated as tracers of petrol products, and methyl substituted alkanes as markers of tobacco smoking.

The saw-tooth distribution of high-molecular-weight n-alkanes has been associated to high trees [Simoneit and Mazurek 1982, Alves et al 2001, Rabhi et al 2018]. Biogenic synthesis leads to preferential generation of even $\mathrm{C}$-numbered fatty acids, then, acids tend to loose $\mathrm{CO}_{2}$ through the natural process of decarboxylation, and form odd-C numbered n-alkanes (or alkenes, in the case of unsaturated precursors) as final products. Since this phenomenon is more evident for long-chain homologues, the most used parameter to rate the impact of (high) vegetation is Carbon Preference Index ( $\left.\mathrm{CPI}_{25}\right)$ [Alves et al 2001, Pio et al 2001, Omar et a 2007]. This parameter is expressed by the following formula:

$$
\mathrm{CPI}_{25}=\frac{\mathrm{C}_{25}+\mathrm{C}_{27}+\mathrm{C}_{29}+\mathrm{C}_{31}+\mathrm{C}_{33}+\mathrm{C}_{35}}{2 *\left(\mathrm{C}_{24}+\mathrm{C}_{26}+\mathrm{C}_{28}+\mathrm{C}_{30}+\mathrm{C}_{32}+\mathrm{C}_{34}\right)}+\frac{\mathrm{C}_{25}+\mathrm{C}_{27}+\mathrm{C}_{29}+\mathrm{C}_{31}+\mathrm{C}_{33}+\mathrm{C}_{35}}{2 *\left(\mathrm{C}_{26}+\mathrm{C}_{28}+\mathrm{C}_{30}+\mathrm{C}_{32}+\mathrm{C}_{34}+\mathrm{C}_{36}\right)}
$$

where $\mathrm{C}_{i}$ means the concentration of n-alkane homologue with carbon number equal to $i$.

By contrast, a mono-modal distribution with the maximum centered between $\mathrm{C}_{19}$ and $\mathrm{C}_{26}$ is typical of exhausts of fuels derived from petroleum, in this case, $\mathrm{CPI}_{25}$ values range from 0.6 to 1.3 [Simoneit 1984, Perrone et al 2014].

For instance, we calculated $\mathrm{CPI}_{25}$ equal to $\sim 1$ and exceeding 10 , respectively, nearby a highway in the Algiers metropolitan area (Fig. 1A), and in a forest area of Biskra province, Algeria (Fig. 1B), instead, usually a combination of the two distributions has observed in a city garden of Rome, Italy (Fig. 1C).

Other indexes have investigated to put in evidence the impact of vegetation. They are: $i$ ) the homologue $\left(\mathrm{C}_{\max }\right)$ corresponding to the maximum concentration within the n-alkane percent distribution, and ii) the cumulative percentage attributable to natural waxes (NW\%) $[36,63]$. As for $\mathrm{C}_{\text {max }}$, motor vehicle exhausts show the prevalence of short and medium chain hydrocarbons $\left(<\mathrm{C}_{24}\right)$, whilst the leaf debris of high trees is characterized by the predominance of $n-C_{29} / n-C_{31}$. The two distinct behaviors have pictured in Fig. $1 \mathrm{~A}$ and $1 \mathrm{~B}$, where the maximums correspond to tricosane $\left(\mathrm{C}_{23}\right)$ and nonacosane $\left(\mathrm{C}_{29}\right)$, respectively.

The NW\% value is provided by the formula:

$$
\mathrm{NW} \%=100 * \frac{\sum_{12}^{m} \mathrm{C}_{2 \mathrm{n}+1}-0.5^{*}\left(\mathrm{C}_{2 \mathrm{n}+2}+\mathrm{C}_{2 \mathrm{n}}\right)}{\sum_{12}^{m} C_{2 n+1}}
$$

Where each term at numerator is set equal to zero whereas the actual rate results $<0$.

Besides, carbon preference indexes analogous to $\mathrm{CPI}_{25}$ have formulated considering larger n-alkane ranges (e.g., $\left.\mathrm{C}_{11} \div \mathrm{C}_{36}\right)$ or the only light homologues $\left(<\mathrm{C}_{25}\right)$, e.g. $\mathrm{C}_{15}-\mathrm{C}_{24}$. Although CPIs based on light 
hydrocarbon sequences are biased due to compound volatility, these indexes allow investigating the possible impact of marine biota (algae, plankton) and microorganisms when they are combined with the presence of isoprenoids and with $C_{\max }$ corresponding to $C_{15} / C_{17}$, [Fisher et al 1972, Horikawa et al 2010, Wang et al 2010]. Table 1 provides a synthetic overview of what discussed above. The action of marine organism has identified also as possible source of squalene and squalane detected in offshore and coastal airborne particulates, while abietane and its homologues allowed distinguishing the coniferous emission from that of other plants and trees [Simoneit and Mazurek 1986, Fine et al 2004].

Despite the above discussed two percent distributions are the most common, $\mathrm{n}$-alkanes belonging to range $<\mathrm{C}_{24}$ may show the prevalence of even-C homologues, this pattern has interpreted as the signature of bacteria and microorganisms [Kuhn et al 2010]. By consequence, it can occur that the whole n-alkane fingerprint exhibits high percentages of even homologues in the short/medium-chain range, and of odd homologues in the long-chain range.

The important presence of petroleum components (e.g. pristane and phytane) compared with $\mathrm{n}-\mathrm{C}_{17}$ and $\mathrm{n}-\mathrm{C}_{18}$, respectively, has considered as a track of motor vehicle emission [Hamilton et al 1984, Alexandrino et al 2019, Alkhafaji 2021]. Though unusual, high percentages of semi-volatile homologues (from $\mathrm{C}_{20}$ to $\mathrm{C}_{26}$ ) have also detected, this pattern has found as typical of particulates contaminated with bee waxes [Guenther et al., 1995, Fine et al., 2004].

2.3.Branched and cyclic hydrocarbons. Complex blends of aliphatic hydrocarbons with branched and/or cyclic structure (e.g., steranes and hopanes, see Figure S1 in Supplementary Material) form the bulk of petrol industry products, like fuels and solvents, and affect the exhausts [Xiao et al 2019]. The composition profile of organic particulates shows one or two humps of "unresolved mixture" which accompany the n-alkanes sequence, the first one, comprised of light hydrocarbons, has associated with gasoline and diesel oil residues, and the second, of heavier components, to lubricating oils (see $a$ and $b$ humps in Fig. 2). Noteworthy, the vehicle emission profile depends on the engine working conditions, the relative importance of hump raises at unregulated driving regimens, e.g. during cold starts.

Both tobacco plant leaves and tobacco smoke fumes exhibit a particular percent profile of the non-polar organic fraction. In fact, long-chain odd iso-alkanes and even anteiso-alkanes are much richer than in other emissions [Kavouras et al., 1998]. Besides, the norma/ hentriacontane $\left(\mathrm{nC}_{31}\right)$ is predominant if compared to $\mathrm{nC}_{29}$ and $\mathrm{nC}_{33}$ homologues. This molecular signature has observed in tobacco smoke chambers and in interiors heavily contaminated by smoke.

2.4. Polycyclic aromatic hydrocarbons. The focus of investigations on PAHs originates from the ascertained toxicity of these substances in terms of carcinogenic and mutagenic power as well as of copromotion of hearth morbidity and premature deaths [Collins et al 1998, European Parliament and Council 2005, IARC 2012]. Since organic particulates exhibit different PAH signatures, many attempts of associating their chemical imprinting with the nature of emission have made. At this regard, it is worth to remark that the actual percentages of PAHs in emissions do not correspond to those found in PM and 
dust [Kim et al 2009, Tobiszewski and Namiesnik 2012, Keyte et al 2013]. Indeed, most PAHs are released hot by organic matter burning (e.g., forest fires, fuel combustion), thus, PAHs originally exist overall as vapors, afterwards, PAHs fast condense onto carbonaceous particles dispersed in air and share their fate (e.g., settle or move across atmosphere) [Simoneit 2002, Medeiros and Simoneit 2008, Ravindra et al 2008, Lammel et al 2010]. The gas/particle equilibrium developing at the particle surface is dynamic and affected by reactivity of congeners, though the principal PAHs (e.g., the sixteen included in the list of priority pollutants [USEPA, 1993]) have classified as persistent toxicants [USEPA 1993, MacKay and Callcott 1998, Lodovici et al 2003, Cao et al 2019].

Only a handful of PAHs, both individually and as sub-groups, have associated to specific sources. Among them, the most important ones are retene (1-methyl,7-isopropylphenanthrene), dimethyl/ethylphenanthrene and benzo[ghi]fluoranthene [Tong and Karasek, 1984, Benner et al., 1995, Shen et al., 2012]. Retene is typical of wood, the second occurs as mixture of isomers labeling differently vegetation and fossil fuel combustion, and the third looks as an important component of motor vehicle exhausts. An example of that has pictured in Fig. 3, which reports the dimethyl/ethyl phenanthrene isomers MS ion trace observed in the airborne particulates of Leonessa and Rome, Italy [Petracchini et al 2017]. The GC-MS chromatogram in Fig. 3A refers to Rome downtown during the winter and mimics that of diesel exhausts. Figure 3B refers to Leonessa, a mountain town of Central Italy, the dimethyl/ethyl phenanthrenes fingerprint is analogous to that of Rome but holds some differences. Another molecular signature of dimethyl/ethyl phenanthrenes, reported in Fig. C, belonged to a second sample of Leonessa (Fig. 3C), although collected in the same year period, it was almost identical to that characterizing the wood burning. Noticeably, wood combustion is plenty exploited in that region to heat houses, cook food and dispose brushwood. The percent distribution in Fig. $3 \mathrm{C}$ is similar to that found in Leonessa during the summer season (Fig. 3D). For completeness of information, Figure 3E reports the GC-MS trace of retene recorded in the second winter sample of Leonessa.

Solely fresh emissions hold benzo[b]anthracene (naphthacene) and anthanthrene, known to be prone to decompose fast [Wise et al 1988, Dominguez et al 2003, Kim et al 2009]. Indeed, the occurrence of these compounds has documented in exhausts but has not regularly in the atmosphere.

Due to contemporary occurrence of a number of PAHs, the usual approach aiming at drawing insights about the nature of emissions considers the concentration ratios of individual substances [Ravindra et al 2008, Katsoyiannis et al 2011, Katsoyiannis and Breivik 2014]. The most common concentration PAH ratios used to identify the sources are fluoranthene vs. pyrene (FA/PY). benz[a]anthracene vs. chrysene $(\mathrm{BaA} / \mathrm{CH})$, indeno[1.2.3-cd]pyrene vs. benzo[ghi]perylene (IP/BPE), and benzo[a]pyrene vs. benzo[ghi]perylene (BaP/BPE). Other ratios, e.g. phenanthrene vs. anthracene (PHE/AN), total methylphenanthrene vs. phenanthrene (SMPHE/PHE) and unsubstituted PAHs vs. total PAHs including alkyl-substituted congeners (parent-PAHs/ SPAHs) are investigated less frequently. Table 2 provides a list of PAH diagnostic ratios and the respective values calculated for several categories of emissions, as described by scientific literature. The lack of unequivocal digits labeling the type of emission leads the Authors to consider small intervals of values for each PAH concentration ratio, and groups of three or four 
pairs of compounds. The benzo[a]pyrene/benzo[e]pyrene ratio (BaP/BeP) merits a separate discussion. Indeed, for a long time BeP has not investigated, because considered poorly carcinogenic with respect to other PAHs. On the other hand, it occurs in emissions at similar extents as benzo[a]pyrene, but is more persistent. Thus, the concentration ratio rate of the two isomers is close to 1.0 in fresh exhausts but tends to drop, overall in the presence of oxidants. For instance, in a monitoring campaign carried out in Milan, Italy, during 1991, we found BaP/BeP concentration ratios 0.9 in February and March, and 0.1 in September, although the sampling location was unchanged and the site was under a quite constant source, namely heavy traffic (Cecinato 1997). Whereas used alone, the information obtained through molecular signatures looks insufficient to quantify the contribution of each source to pollution, however, it helps to recognize the principal sources. Besides, to put in the evidence the degradation of primary emissions begins important when the toxicity of final products (e.g., PAH quinones and lactones) exceeds that of the parent compounds [Durant et al 1999].

2.5. Nitrated polycyclic aromatic hydrocarbons (NPAHs). NPAHs gained concern when it was demonstrated that emissions contain many chemical belonging to this group [Hoekman 1992, Zielinska et al 2004, Liu et al 2010]. These investigations based its raison d'etre in the huge increment of diesel engine vehicles during '70s and ' 80 s of the last century, promoted by tax benefits. In fact, diesel engines have recognized as major sources of NPAHs, capable of giving reason for the NPAH occurrence in the atmosphere [Bamford and Baker 2003, Bandowe et al 2014, Bandowe and Meusel 2017]. On the other hand, many NPAHs have ascertained as direct mutagens and cancer promoters [Gbeddy et al 2020]. Attention has paid overall to a list of NPAHs whose contribution to toxicity of air particulates has even estimated, they are nitrated derivatives of naphthalene, fluorene, anthracene, fluoranthene, pyrene, benz[a]anthracene and chrysene.

However, $\mathrm{NO}_{2}$-position isomers associated to $\mathrm{PM}$ do not correspond to those mainly affecting emissions. In particular, 2-nitrofluoranthene and 2-nitropyrene are commonly absent in exhausts, but exist as products of in-situ reactions developing in the atmosphere (see Figure 4A/B) and sometimes are the most abundant NPAH affecting airborne particulates [Bamford and Baker 2003, Bandowe and Meusel 2017].

The molecular signature nitrofluoranthenes and nitropyrenes has used to parameterize the relative importance of direct emission and action of oxidants. Taking in account the nitration rate of precursors reacting with $\mathrm{OH}$ radicals and $\mathrm{NO}_{2}$, it has suggested that photochemical reactivity is more important than vs. direct emission when the 2-NFA/1-NPY ratio exceeds the value of 5 [Pitts et al, 1985]. Instead, the formation of 4-NPY is feasible only in the presence of $\mathrm{NO}_{3}$ or $\mathrm{N}_{2} \mathrm{O}_{5}$ which develop after sunset through reaction of $\mathrm{O}_{3}$ and $\mathrm{NO}_{2}$.

2.6. Fatty acids and alcohols, polar compounds. Medium and long-chain acids exist overall as released by living organisms [Goutx and Saliot 1980, Kawamura and Gagosian 1987, Lindbeck and Puxbaum 1999, Oliveira et al 2007, Bi et al 2008, Sangiorgi et al 2013, Balducci et al 2014]. The percent distribution pattern of fatty acids reveals the clear prevalence of even carbon atom homologues, and the rates of carbon preference indexes (ACPIs), formulated similarly to those of n-alkanes, can exceed the rate of ten 
[Alves and Pio, 2001]. Other sources show analogous profiles, e.g., vehicle exhausts hold $A_{12}-A_{22}$ acids (i.e., linear chain homologues with $12 \div 22$ carbon atoms), with the maximums corresponding to $A_{16}$ and $A_{18}$. Biogenic emissions show also typical percentages of medium- and long-chain fatty acids. Usually, apart from palmitic $\left(A_{16}\right)$ and stearic $\left(A_{18}\right)$ acids, the profiles have a secondary maximum within the ranges $A_{20} \div A_{24}$, or $>A_{25}$, light homologues have associated with microbiota, small plants, softwood trees, while heavy acids characterize high plants and hardwood trees [Gelpi et al., 1970]. Besides, in the case of microorganisms the ACPI rates are lower, due to important percentages of odd-carbon acids from $A_{15}$ to $\mathrm{A}_{21}$.

Unsaturated and dicarboxylic acids merit a special mention. Unsaturated acids $\left(U A_{n}\right)$, e.g. palmitoleic $\left(U A_{16}\right)$, oleic $\left(U_{18}\right)$ and linoleic (twin unsaturated $\left.A_{18}\right)$, are indicative of emission from crops.

Dicarboxylic fatty acids $\left(\mathrm{DA}_{\mathrm{n}}\right)$ exist as minor components released by vegetation, whose emissions show the usual even-to-odd carbon prevalence, however particulate matters are rich of $D_{2}-D_{6}$ homologues, due to contribution of anthropogenic sources. Nevertheless, reacted air parcels reveal the important occurrence of azelaic acid ( $\left.\mathrm{DA}_{g}\right)$, which is a by-product of oleic acid decomposition [Balducci et al 2014, Kawamura and Bikkina 2016, Ren et al 2020].

Linear alcohols, 2-ketones, aldehydes, fatty acid methyl esters and nitriles have not extensively investigated as source tracers of suspended particulates, though all of them have linked to emission from vegetation [Simoneit and Mazurek 1982, Simoneit 2002] and have found in pyrolysis by-products of sewage sludge treated with aerobic and anaerobic digestion [Dominguez et al 2003]. Linear alcohols exhibit a behavior parallel to fatty acids. They display the predominance of even carbon homologues and are among the principal components of organic particulates in rural regions [Simoneit and Mazurek 1982]. Many sterols also (e.g., sitosterol, stigmasterol and amyrins) have associated to vegetation as components of epicuticular waxes. The most important exception is cholesterol, which has recognized as a tracer of meat cooking [Cass 1998, Carreira et al 2009]. Other acid esters (including biopolymers) are employed nowadays as alkyl phthalate surrogates, because these latter have classified as emerging contaminants [Cavanah et al 2018, Udayakumar et al 2021]. Thus, the occurrence of new esters in soot and dust is indicative of contamination by plastics.

A set of polar organics, including nicotine and its derivatives, e.g. cotinine and nitrosamines, have proposed as tracers of mainstream, sidestream and third-hand tobacco smoke [Hecht 1999, Hammond et al 1987, Daisey 1999, Apelberg et al 2013, Blanchard et al 2014], nevertheless, quantitative estimates of impact on the environment have attempted only by means of nicotelline [Aquilina et al 2021].

2.7. Organic halides. Polychlorobiphenyls (PCBs) and polychlorinated dioxins and furans (PCDD/Fs) are probably the most investigated groups of halides affecting the environment [Barbas et al 2018]. PCBs were important industrial products, because they had a number of applications as mixtures (power transformers, heat exchangers, substrates for pesticides and inks, solvents), by contrast, PCDDs and PCDFs exist solely as unwanted by-products of other industrial processes (e.g., paint manufacturing, 
foundries and steel mill). Despite PCBs and PCDD/Fs have banned since long time, both groups still affect the environment [ $\mathrm{Ngo}$ et al 2020]. Industrial syntheses of PCBs lead to blends characterized by various average chlorine percentages, which sometimes could aid in highlighting the impact of sources suspected to cause environmental pollution. Various fingerprints label the emission sources, for instance, distinct PCDD/Fs patterns have observed for vehicle exhausts and steel mill fumes [Liu et al 2015]. Besides that, the molecular fingerprints of PCBs and PCDD/Fs change with time owing to ability of congeners to persist to degradation as well as to dissolve in waters and lipids [Di Guardo et al 2017, Ngo et al 2018, Ngo et al 2020]. Finally, it is very important to take in account the not negligible volatility of organic halides. For instance, 2.3.7.8-tetrachlorodibenzo-p-dioxin occurs exists overall as vapor in the environment, whilst dioxin-like congeners are adsorbed on particulates [Barbas et al 2018], owing to their key role in toxicity, the contemporary collection of gaseous and condensed phases of atmosphere and emissions is mandatory to draw information about sources and air quality.

Other halides have recently gained importance, as tracers of water, air and soil pollution caused by waste spill and contaminated food. In particular, polybromodiphenyl ethers (PBDEs) and organic esters of phosphoric acid are present in flame retardant formulas [Lee et al 2020, Percy et al 2020], while perfluoroalkyl acids (PFAs) and other perfluorinated chemicals enjoy of many industrial and home care applications as surfactants [Hubbard et al 2012].

2.8. Polysaccharides. The occurrence of numerous organic substances in the environment has recognized as linked with biomass burning in general, and specifically to that of specific tree species [Oros and Simoneit 2001a/b, Oros et al 2002]. Many are the by-products of lignine (e.g., methoxyphenols) [Hawthorne et al 1988, Hays et al 2005], as well as those emerging from dehydration-polymerization of carbohydrate molecules (levoglucosan, galactosan, mannosan, inositols). Levoglucosan in particular, typical tracer of wood burning, allowed to demonstrate that even big city downtowns undergo the impact of this kind of emission, due to the generalized use of wood for heating and cooking [Fine et al., 2004] in the countryside. Indeed, wide uncertainty remains associated to the emission rate of these chemicals, nevertheless, according to levoglucosan levels in air, manmade biomass burning looks as the principal source of pollution outside of cities and heavy industry districts [Pomata et al 2014, Perrino et al 2019, Ren et al 2020].

\section{Materials And Methods}

To improve the knowledge of molecular signature of particulate organic matters, we investigated the chemical composition of groups of samples collected in Italy and abroad. The samples were collected from air both indoors and outdoors (airborne particulates and settled dusts). All of them have analyzed in the frame of cooperative research programs with Regional Agencies for Air Pollution Control, Italy, Universities of Algiers (USTHB) and Ouargla, Algeria, Technopolis of Borj Cedria, Tunisia, Ministry of the Environment (MATTM), Italy, as well as proprietary CNR-IIA projects. 
The sampling procedures and the analytical methods adopted to characterize the composition of targeted particulates are described elsewhere [Ciccioli et al 1989, Yassaa et al 2001, Mabilia et al 2004, Mininni et al 2004, Paolini et al 2015, Rabhi et al 2018]. Sampling procedures in compliance with European normative for $\mathrm{PM}_{10}$ have applied. They consisted of active aspiration of air at $2.32 \mathrm{~m} / \mathrm{h}$ flow rate and filtration through inert membranes in Teflon. Settled dust has collected from free surfaces according to the method optimized in our institute [Cecinato et al 2014, Romagnoli et al 2014]; ultra-pure aluminum foils or cotton swabs have stretched out over pre-cleaned surfaces at $1.5 \div 2.0 \mathrm{~m}$ above ground and exposed 15 days. To minimize changes in chemical composition, the samples have individually sealed in plastic boxes and stored in a freezer until analysis.

Procedures adopted to solve chemical composition of samples comprised: i) extraction with organic solvent; ii) fractionation; and iii) instrumental analysis through gas chromatography - mass spectrometry (GC-MS) [Cecinato et al 2014, Romagnoli et al 2014, Mabilia et al 2004, Paolini et al 2015]. Organic fraction has recovered from the substrate through extraction in ultrasonic bath, using a dichloromethane/acetone mixture. After reduction close to dryness, the extracts have fractionated through chromatography on neutral alumina or silica gel column; three classes of polarity have separated through eluting the column with isooctane, isooctane/dichloromethane and dichloromethane/acetone, in sequence. Instrumental analysis was performed by applying GC-MS methods based on (DB5-MS type) capillary column separation, electron-impact ionization of analyte molecules and total ion current (TIC) or selected-ion (SIM) recording. Injection has operated in split-less mode, chromatographic runs has conducted in gradient of temperature up to $290^{\circ} \mathrm{C}$, and peak recognition achieved by means of characteristic molecule and fragment ion current signals, coupled with peak retention times. The internal standard method, based on the use of perdeuterated homologues as reference of native compounds, has adopted for quantitative purposes.

\section{Results And Discussion}

Until now, scarce attention has paid to unsaturated hydrocarbons. Nevertheless, in the light range of nonpolar fraction of POM (corresponding to hydrocarbons with 12 up to 20 carbon atoms in the molecule, namely $\mathrm{C}_{12} \div \mathrm{C}_{20}$ ) we could distinguish three distinct fingerprints. They were: $i$ ) the predominant occurrence of n-alkanes (n-alkenes negligible); ii) the prevalence of n-alkenes (with high dodecene/dodecane and tetradecene/tetradecane ratios, and low octadecene/octadecane and eicosene/eicosane ratios); and iii) a mixed behavior. The three fingerprints have shown in Figure 5. Sample A (dust collected indoors at El Bey, Tunisia, held much more n-alkanes than alkenes (Fig. 5A1/A2); dusts from Tipaza, Algeria (Fig. 5B1/B2) included both alkanes and alkenes; n-alkene concentrations exceeded those of $n$-alkanes in dusts of Reggio Calabria, Italy (Fig. 5C1/C2).

At our knowledge, no exhaustive explanation of the three distinct patterns has provided. Even n-alkene homologues presumably are directly released by unknown sources or originate from the twofold decarboxylation of unsaturated even a,w-diacids, but further investigations are needed to link these fingerprints with anthropogenic and biogenic emissions. 
As for tobacco smoking, both in airborne particulate and dust collected at a frequent smoker's home in Rome, Italy, anteiso $\mathrm{C}_{30}, \mathrm{C}_{32}$ and $\mathrm{C}_{34}$ alkanes were more abundant than the respective normal homologues. Besides, the concentration of normal $\mathrm{C}_{31}$ exceeded the average of $\mathrm{nC}_{29}$ and $\mathrm{nC}_{33}$. Both molecular signatures are similar to those found in smoke chambers (Figure 6).

According to that, we have tried to pinpoint two new quantities to index the impact of tobacco smoking on the environment. They are average tobacco smoke ratio (ATSR) and average anteiso/iso concentration ratio (AICR), defined by the following formulas:

ATSR $=\left(\mathrm{iC}_{29} / \mathrm{nC}_{29}+\mathrm{aC}_{30} / \mathrm{nC}_{30}+\mathrm{iC}_{31} / \mathrm{nC}_{31}+\mathrm{aC}_{32} / \mathrm{nC}_{32}+\mathrm{iC}_{33} / \mathrm{nC}_{33}+\mathrm{aC}_{34} / \mathrm{nC}_{34}\right) / 6$

AICR $=\left(\mathrm{aC}_{29} / \mathrm{iC}_{29}+\mathrm{aC}_{30} / \mathrm{iC}_{30}+\mathrm{aC}_{31} / \mathrm{iC}_{31}+\mathrm{aC}_{32} / \mathrm{iC}_{32}+\mathrm{aC}_{33} / \mathrm{iC}_{33}+\mathrm{aC}_{34} / \mathrm{iC}_{34}\right) / 6$

where $\mathrm{iC}_{\mathrm{j}}, \mathrm{aC}_{\mathrm{j}}$ and $\mathrm{nC}_{\mathrm{j}}$ indicate iso-, anteiso- and linear alkanes with $\mathrm{j}$ carbon atoms in the molecule.

Instead of identifying one only ratio among the anteiso/iso/normal alkane sequence, we computed all concentration ratios of ATSR and AICR formulas over the $\mathrm{C}_{29}-\mathrm{C}_{34}$ range in order to reduce uncertainty associated to small changes in emission profiles of other possible sources. To assess the correctness of this approach, both ATSR and AICR rates have evaluated in airborne particulates and dusts collected both at urban and rural sites. The results have shown in Table 3 .

ATSR values ranged from 0.05 to 1.30 , with the minimums corresponding to rural sites and the maximums found in locations heavily affected by tobacco smoke. ATSR and AICR values calculated in the case of outdoor samples put in the evidence the impact of tobacco smoking, which was in agreement with the ubiquitous occurrence of nicotine in the city air [Rabhi et al 2018 and references herein]. In general, dusts showed ATSR and AICR values lower than airborne particulates; that is in accordance with the nature of dust, which includes coarse grains of various origin, whilst tobacco smoke is comprised of fine and ultra-fine particles accounting for only a fraction of total particulate mass. Noticeably, ATSR and AICR values in the dust and at the balcony of smoker house (see the sixth column of Table 3 ) were quite high, confirming the importance of tobacco smoke in interiors and even at open air. Though still insufficient to draw semi-quantitative information about the contribution of tobacco smoke to environmental pollution, the molecular signature of long-chain alkanes, seems more attractive than nicotine and its derivatives, which are more volatile and degradable. Presumably, it can suitably combine with the monitoring of nicotelline.

\section{Conclusion}

Molecular signature of organic contaminants affecting airborne particulates and dusts comprise individual markers and, more often, distribution patterns within the homologue groups. Both tools provide preliminary but suitable information about nature of emissions and with regard to their health impact on environment. Further investigations are necessary to elucidate the sources of chemical fingerprints newly observed. In particular, the progress in knowledge of molecular fingerprints will help investigators in 
applying more sophisticated approaches (e.g., principal component analysis, source factorization modelling) to assess the relative importance of emissions. That will help to optimize the strategies aimed at controlling air pollution and mitigating the toxicants impact on humans and environment.

\section{Declarations}

Author Contributions. This paper originates from specific contributions of the Authors. They are:

Dr. Angelo Cecinato (angelo.cecinato@uniroma1.it; angelo.cecinato@iia.cnr.it): result analysis, conceptualization of molecular signature indexing, original and revised draft preparation, writing and editing;

Prof. Alessandro Bacaloni (alessandro.bacaloni@uniroma1.it): supervision and training of doctorate thesis work;

Dr. Paola Romagnoli (romagnoli@iia.cnr.it): chemical analysis of dust and suspended particulate samples;

Tech. Mattia Perilli (perilli@iia.cnr.it): in-field campaign preparation, performance and management; paper reviewing;

Dr. Catia Balducci (balducci@iia.cnr.it): chemical procedure setup; sample analysis; investigation performance and management; writing (reviewing, revised manuscript editing).

Funding. This research received no external funding.

Ethical Approval and Consent to Participate: This study did not involve experiments on humans or animals. It consisted of analysis of literature regarding chemical composition of tobacco smoke, as well as of data series about organic matter associated to airborne particulates and dusts, set up in the frame of research programs performed by the Authors.

Institutional Review Board Statement. Not applicable: This study did not involve tests on humans or animals.

Informed Consent Statement. Not applicable (no experiments have made on humans or animals).

Consent to Publish: All Authors agreed on submitting the manuscript, to publish it in ESPR Journal Editorial Board.

Consent for Publication: Not applicable. The manuscript does not contain any individual person's data, since none was subject of investigation nor personal data treatment.

Data availability. The datasets used and/or analysed during the current study are available from the corresponding author on reasonable request. Anyway, those not directly produced by personal 
investigations of Authors are available in the bibliography cited in the paper.

Conflicts of Interest. The authors declare they are not under any conflict of interest condition.

\section{References}

1. Albaiges J, Grimalt J, Bayona JM, Risegrough IR, De Lappe B, Walker W (1984). Dissolved, particulate and sedimentary hydrocarbons in a deltaic environment. Org Geochem 6, 237-248,

2. Alexandrino GL, Tomasi G, Kienhuis PGM, Augusto F, Christensen JH (2019). Forensic investigations of diesel oil spills in the environment using comprehensive two-dimensional gas chromatography high resolution mass spectrometry and chemometrics: New perspectives in the absence of recalcitrant biomarkers. Environ Sci Technol 53, 550-559.

3. Alkhafaji MW (2021). Biomarker assessment of oil biodegradation, water washing, and source rock characteristics of oil seeps from the Foothill Zone along the Tigris River, Northern Iraq. J Petrol Sci Engin, in press. https://doi.org/10.1016/j.petrol.2020.107946.

4. Alves C, Pio C, Duarte A. (2001). Composition of extractable organic matter of air particles from rural and urban Portuguese areas. Atmos Environ 35, 5485-5496.

5. Apelberg BJ, Hepp L M, Avila-Tang E, Gundel L, Hammond SK, Hovell MF, Hyland A, Klepeis NE, Madsen CC, Navas-Acie A, Repac J, Same JM, Breyss PN (2013). Environmental monitoring of secondhand smoke exposure. Tobacco Control 22, 147-155.

6. Aquilina NJ, Havel CM, Cheung P, Harrison RM, Ho KF, Benowitz L, Jacob P III (2021). Ubiquitous atmospheric contamination by tobacco smoke: Nicotine and a new marker for tobacco smokederived particulate matter, nicotelline. Environ Int 150, 106417. DOI: 10.1016/j.envint.2021.106417

7. Arey J and Atkinson R (2003). Photochemical reactions of PAHs in the atmosphere. In: PAHs. An ecotoxicological perspective. Douben P.E.T. Ed., John Wiley \& Sons Ltd, Chichester, England, pp.4763.

8. Atkinson R and Arey J (1994). Atmospheric chemistry of gas-phase polycyclic aromatic hydrocarbons: formation of atmospheric mutagens, Environ Health Perspec 102, Suppl. 4, 117-126.

9. Balducci C, Ladji R, Muto V, Romagnoli P, Yassa, N, Cecinato A (2014). Biogenic and anthropogenic organic components of Saharan sands. Chemosphere 107, 129-135.

10. Bamford HA and Baker JE (2003). Nitro-polycyclic aromatic hydrocarbon concentrations and sources in urban and suburban atmospheres of the Mid-Atlantic region. Atmos Environ 37, 2077-2091.

11. Bandowe BAM and Meusel $H$ (2017). Nitrated polycyclic aromatic hydrocarbons (nitroPAHs) in the environment - a review. Sci Total Environ 581-582, 237-257.

12. Bandowe BAM, Meusel H, Huang R, Ho K, Cao J, Hoffmann T, Wilcke W (2014). PM 2.5 -bound oxygenated PAHs, nitro-PAHs and parent-PAHs from the atmosphere of a Chinese megacity: Seasonal variation, sources and cancer risk assessment. Sci Total Environ 473-474, 77-87. 
13. Barbas B, de la Torre A, Sanz P, Navarro I, Artíñano B, Martínez MA (2018). Gas/particle partitioning and particle size distribution of PCDD/Fs and PCBs in urban ambient air. Sci Total Environ 624, 170179.

14. Bascom R, Bromberg PA, Costa DA, Devlin R, Dockery DW, Frampton MW, Lambert W, Samet JM, Speizer FE, Utell M (1996). Health effects of outdoor air pollution- Part 1. American J Resp Crit Care Med 153, 3-50.

15. Benner BA Jr, Wise SA, Currie LA, Kloud GA, Klinedinst DB, Zweidinge, RB, Stevens RK, Lewis CW (1995). Distinguishing the contributions of residential wood combustion and mobile source emissions using relative concentrations of dimethylphenanthrene isomers. Environ Sci Technol 29, 2382-2389.

16. Bi X, Simoneit BRT, Sheng G, Ma S, Fy J (2008). Composition and major sources of organic compounds in urban aerosols. Atmos Res 88, 256-265.

17. Blanchard O, Glorennec P, Mercier F, Bonvallot N, Chevrier C, Ramalho O, Mandin C, Le Bot B (2014). Semivolatile organic compounds in indoor air and settled dust in 30 French dwellings. Environ Sci Technol 48, 3959-3969.

18. Błaszczyk E, Rogula-Kozłowska W, Klejnowski K, Kubiesa P, Fulara I, Mielżyńska-Švach D (2017). Indoor air quality in urban and rural kindergartens: short-term studies in Silesia, Poland. Air Quality, Atmosphere \& Health 10, 1207-1220.

19. Brehmer C, Norris C, Barkjohn KK, Bergin MH, Zhang J, Cui X, Teng Y, Zhang Y, Black M, Li Z, Shafer MM (2020). The impact of household air cleaners on the oxidative potential of $\mathrm{PM}_{2.5}$ and the role of metals and sources associated with indoor and outdoor exposure. Environ Res 181, 108919.

20. Brown AS and Brown RJC (2012). Correlations in polycyclic aromatic hydrocarbon (PAH) concentrations in UK ambient air and implications for source apportionment. J Environ Monit 14, 2072-2082

21. Brown RJC and Brown AS (2012). Principal component analysis as an outlier detection tool for polycyclic aromatic hydrocarbon concentrations in ambient air, Water Air Soil Poll 223, 3807-3816.

22. Cao Z, Wang M, Chen Q, Zhu C, Jie J, Li X, Dong X, Miao Z, Shen M, Bu Q (2019). Spatial, seasonal and particle size dependent variations of PAH contamination in indoor dust and the corresponding human health risk. Sci Total Environ 653, 423-430.

23. Carreira RS, Ribeiro PV, Silva CEM (2009). Hydrocarbons and sterols as indicators of sources and destination of organic matter in sediments of Sepetiba Bay, Rio de Janeiro. Chem Nova 32, 18051811

24. Cass GR (1998). Organic molecular tracers for particulate air pollution sources. Trends Anal Chem $17,356-366$.

25. Cavanagh JAE, Trought K, Mitchell C, Northcott G, Tremblay LA (2018). Assessment of endocrine disruption and oxidative potential of bisphenol-A, triclosan, nonylphenol, diethylhexyl phthalate, galaxolide, and carbamazepine, common contaminants of municipal biosolids. Toxicol. in Vitro 48, 342-349. 
26. Cecinato A (1997). Polynuclear aromatic hydrocarbons (PAH), benz(a)pyrene (BaPY) and nitratedPAH (N-PAH) in suspended particulate matter. Annali di Chimica 87, 483-496.

27. Cecinato A, Guerriero E, Balducci C, Muto V (2014). Use of the PAH fingerprints for identifying pollution sources. Urban Climate 10, 630-643.

28. Cetin B, Yurdakul S, Gungormus E, Ozturk F, Sofuoglu SC (2018). Source apportionment and carcinogenic risk assessment of passive air sampler-derived PAHs and PCBs in a heavily industrialized region. Sci Total Environ 633, 30-41.

29. Chen YY, Kao TW, Wang CC, Chen YJ, Wu CJ, Lai CH, Chen WL (2019). Exposure to polycyclic aromatic hydrocarbons and risk of disability among an elderly population. Environ Sci Pollut Res 26, 10719-10726.

30. Ciccioli P, Cecinato A, Brancaleoni E, Draisci R, Liberti A (1989). Evaluation of Nitrated Polycyclic Aromatic Hydrocarbons in Anthropogenic Emission and Air Samples: A Possible Means of Detecting Reactions of Carbonaceous Particles in the Atmosphere. Aerosol Sci Technol 10, 296-310.

31. Collins JF, Brown JP, Alexceff GV, Salmon AG (1998). Potency equivalency factors for some polycyclic aromatic hydrocarbons and polycyclic aromatic hydrocarbon derivatives. Regul Toxicol Pharmacol 28, 45-54.

32. Daisey J M (1999). Tracers for assessing exposure to environmental tobacco smoke: what are they tracing? Environ Health Perspect 107 (Suppl. 2), 319-327.

33. Daisey JM, Cheney JL, Lioy PJ (1986). Profiles of organic particulate emissions from air pollution sources: status and needs for receptor source apportionment modelling. J Air Pollut Control Assoc 36, 17-33.

34. Damanik N, Ong HC, Tong CW, Mahlia TMI, Silitonga AS (2018). A review on the engine performance and exhaust emission characteristics of diesel engines fueled with biodiesel blends. Environ Sci Pollut Res 25, 15307-15325.

35. Di Guardo A, Terzaghi E, Raspa G, Borin S, Mapelli F, Chouaia B, Zanardini E, Morosini C, Colombo A, Fattore E, Davoli E, Armiraglio S, Sale VM, Anelli S, Nastasio P (2017). Differentiating current and past PCB and PCDD/F sources: The role of a large contaminated soil site in an industrialized city area. Environ Pollut 223, 367-375.

36. Dominguez A, Menendez JA, Inguanzo M, Bernad PL, Pis JJ (2003). Gas chromatographic-mass spectrometric study of the oil fractions produced by microwave-assisted pyrolysis of different sewage sludges. J Chromatog. A 1012, 193-206.

37. Durant JL, Busby WF Jr, Lafleur AL, Penman BW, Crespi CL (1999). Human cell mutagenicity of oxygenated, nitrated and unsubstituted polycyclic aromatic hydrocarbons associated with urban aerosols. Mutat Res 371, 123-157.

38. Eglinton G, Gonzalez AG, Hamilton, RJ, Raphael RA (1962). Hydrocarbon constituents of the wax coatings of plant leaves: a taxonomic survey. Phytochem 1, 89-102.

39. Estève W, Budzinski $\mathrm{H}$, Villenave $\mathrm{E}$ (2004). Relative rate constants for the heterogeneous reactions of $\mathrm{OH}, \mathrm{NO}_{2}$ and $\mathrm{NO}_{3}$ radicals with polycyclic aromatic hydrocarbons adsorbed on carbonaceous 
particles. Part 1: PAHs adsorbed on 1-2 mm calibrated graphite particles. Atmos Environ 38, 60636072.

40. European Parliament and Council (2005). Directive 2004/107/EC of the European parliament and of the council of 15 December 2004 relating to arsenic, cadmium, mercury, nickel and polycyclic aromatic hydrocarbons in ambient air. Official J Europ Union 23, 1-16, (26/01/2005).

41. Fine PM, Cass GR, Simoneit BRT (2004). Chemical characterization of fine particle emissions from the wood stove combustion of prevalent United States tree species. Environ Engin Sci 21, 705-721.

42. Fisher DJ, Holloway PJ, Richmond DV (1972). Fatty acid and hydrocarbon constituents of the surface and wall lipids of some fungal spores. J General Microbiol 72, 71-78.

43. Gbeddy G, Egodawatta P, Goonetilleke A, Ayoko G, Chen L (2020). Application of quantitative structure-activity relationship (QSAR) model in comprehensive human health risk assessment of PAHs, and alkyl-, nitro-, carbonyl-, and hydroxyl-PAHs laden in urban road dust. J Hazard Mater 383, 121154.

44. Gelpi E, Schneider H, Mann J, Oro J (1970). Hydrocarbons of geochemical significance in microscopic algae. Phytochem 9, 603-612.

45. Giulivo M, Lopez de Alda M, Capri E Barceló, D (2016). Human exposure to endocrine disrupting compounds: Their role in reproductive systems, metabolic syndrome and breast cancer. A review. Environ Res 151, 251-264.

46. Goutx M, Saliot A (1980). Relationship between dissolved and particulate fatty acids and hydrocarbons, chlorophyll a and zooplankton biomass in Villefranche Bay, Mediterranean Sea. Marine Chem 8, 299-318.

47. Guenther A, Hewitt CN, Erickson D, Fall R, Geron C, Graedel T, Harley P, Klinger L, Lerdau M, McKay WA, Pierce T, Scholes B, Steinbrecher R, Tallamraju R, Taylor J, Zimmerman PJ (1995). A global model of natural volatile organic compounds emissions. J. Geophys. Res. Atmosphere 100, 88738892.

48. Gundel LA, Daisey JM, de Carvalho RF, Kado NY, Schuetzle D (1993). Polar organic matter in airborne particles. Chemical characterization and mutagenic activity. Environ Sci Technol 27, 2112-2119.

49. Guo Y and Kannan K (2013). A survey of phthalates and parabens in personal care products from the United States and its implications for human exposure. Environ Sci Technol 47, 14442-14449.

50. Hamilton SE, Bates TS, Cline GL (1984). Sources and transport of hydrocarbons in the GreenDuwamish River, Washington. Environ Sci Technol 18, 72-79.

51. Hammond SK, Leaderer BP, Roche AC, Schenker M (1987). Characterization of contaminant emissions from indoor sources collection and analysis of nicotine as a marker for environmental tobacco smoke. Atmos Environ 21, 457-462.

52. Harrison RM, Smith DJT, Luhanan L (1996). Source apportionment of atmospheric polycyclic aromatic hydrocarbons collected from an urban location in Birmingham, UK. Environ Sci Technol 30, 825-832. 
53. Hassanvand MS, Naddafi K, Faridi S, Nabizadeh R, Sowlat MH, Momeniha F, Gholampour A, Arhami M, Kashani H, Zare A, Niaz, S (2015). Characterization of PAHs and metals in indoor/outdoor PM10/PM2.5/PM1 in a retirement home and a school dormitory. Sci Total Environ 527, 100-110.

54. Hawthorne SB, Miller DJ, Barkley RM, Krieger MS (1988). Identification of methoxylated phenols as candidate tracers for atmospheric wood pollution. Environ Sci Technol 22, 1191-1196.

55. Hays MD, Fine PM, Geron CD, Kleeman MJ, Gullett BK (2005). Open burning of agricultural biomass: Physical and chemical properties of particle-phase emissions. Atmos Environ 39, 6747-6764.

56. Hecht S (1999). Tobacco smoke carcinogens and lung cancer. J Natl Cancer Inst 91, 1194-1210.

57. Hoekman S K (1992). Speciated measurements and calculated reactivities of vehicle exhaust emissions from conventional and reformulated gasolines. Environ Sci Technol 26, 1206-1216.

58. Horikawa K, Murayama M, Minagawa M, Kato Y, Sagawa T (2010). Latitudinal and downcore (0-750 ka) changes in n-alkane chain lengths in the eastern equatorial Pacific. Quaternary Res 73, 573-582.

59. Hubbard H, Guo Z, Liu X, KrebsK, Roache N, Mocka C (2012). Perfluorinated chemicals in consumer articles - Monitoring the market trends. Reproduct Toxicol 33, 590.

60. IARC (2012). International Agency for Research on Cancer. A review of human carcinogens. Part F: Chemical agents and related occupations. IARC monographs on the evaluation of carcinogenic risks to humans.

61. Jedynska A, Hoek G, Eeftens M, Cyrys J, Keuken M, Ampe C, Beelen R, Cesaroni G, Forastiere F, Cirach $M$, de Hoogh K (2014). Spatial variations of PAH, hopanes/steranes and EC/OC concentrations within and between European study areas. Atmos Environ 87, 239-248.

62. Katsoyiannis A and Breivik K (2014). Model-based evaluation of the use of polycyclic aromatic hydrocarbons molecular diagnostic ratios as a source identification tool. Environ Pollut 184, 488494.

63. Katsoyiannis A, Sweetman AJ, Jones KC (2011). Diagnostic ratios applied to atmospheric sources: A critical evaluation using two decades of source inventory and air concentration data from the UK. Environ Sci Technol 45, 8897-8906.

64. Kavouras IG, Koutraki P, Cereceda-Bali F, Oyol P (2001). Source apportionment of urban particulate aliphatics and polynuclear aromatic hydrocarbons (PAHs) using multivariate methods. Environ Sci Technol 35, 2288-2294.

65. Kavouras IG, Stratigakis N, Stephanou EG (1998). Iso- and anteiso-alkanes: specific tracers of environmental tobacco smoke in indoor and outdoor particle-size distributed urban aerosols. Environ Sci Technol 32, 1369-1377.

66. Kawamura K, Bikkina S (2016). A review of dicarboxylic acids and related compounds in atmospheric aerosols: Molecular distributions, sources and transformation. Atmos Res 170, 140-160.

67. Kawamura K, Gagosian RB (21987). Implications of w-oxocarboxylic acids in the remote atmosphere for photo-oxidation of unsaturated fatty acids. Nature 325, 330-332. 
68. Keyte IJ, Harrison RM, Lammel G (2013). Chemical reactivity and long-range transport potential of polycyclic aromatic hydrocarbons-a review. Chem Soc Rev 42, 9333-9391.

69. Khedidji S, Balducci C, Ladji R, Cecinato A, Perilli M, Yassaa N (2017). Chemical composition of particulate organic matter at industrial, university and forest areas located in Bouira province, Algeria. Atmos Pollut Res 8, 474-482.

70. Kim D, Kumfer BM, Anastasio C, Kennedy IM, Young TM (2009). Environmental aging of polycyclic aromatic hydrocarbons on soot and its effect on source identification. Chemosphere 76, 1075-1081

71. Kuhn TK, Krull ES, Bowater A, Grice K, Gleixner G (2010). The occurrence of short chain n-alkanes with an even over odd predominance in higher plants and soils. Org Geochem 41, 88-95.

72. Lammel G, Klánová J, llic P, Kohoutek J, Gasič, B., Kovačič, I, Skrdlíková L (2010). Polycyclic aromatic hydrocarbons in air on small spatial and temporal scales e II. Mass size distributions and gasparticle partitioning. Atmos Environ 44, 5022-5027.

73. Lee HK, Kang H, Lee S, Kim S, Choi K, Moon HB (2020). Human exposure to legacy and emerging flame retardants in indoor dust: A multiple-exposure assessment of PBDEs. Sci Total Environ 719,

74. Lindbeck $A$ and Puxbaum $H$ (1999). Organic acids in continental background aerosols. Atmos Environ 33, 1847-1852.

75. Liu G, Jiang X, Wang M, Dong S, Zheng M (2015). Comparison of PCDD/F levels and profiles in fly ash samples from multiple industrial thermal sources. Chemosphere 133, 68-74.

76. Liu B, Xue Z, Zhu X, Jia C (2017). Long-term trends (1990-2014), health risks, and sources of atmospheric polycyclic aromatic hydrocarbons (PAHs) in the US. Environ Pollut 220, 1171-1179.

77. Liu N, Xu L, Cai Y (2018). Methyl siloxanes in barbershops and residence indoor dust, and the implication for human exposures. Sci Total Environ 618, 1324-1330.

78. Liu ZG, Berg DR, Vasys VN, Dettmann MF, Zielinska B, Schauer JJ (2010). Analysis of $C_{1}, C_{2}$, and $C_{10}$ through $\mathrm{C}_{33}$ particle-phase and semi-volatile organic compound emissions from heavy-duty diesel engines. Atmos Environ 44, 1108-1115.

79. Lodovici M, Venturini M, Marini E, Grechi D, Dolara P (2003). Polycyclic aromatic hydrocarbons air levels in Florence, Italy, and their correlation with other air pollutants. Chemosphere 5, 377-382.

80. Lu J, Li H, Luo Z, Lin H, Yang Z (2018). Occurrence, distribution, and environmental risk of four categories of personal care products in the Xiangjiang River, China. Environ Sci Pollut Res 25, 2752427534.

81. Lucattini L, Poma G, Covaci A, de Boer J, Lamoree MH, Leonards PEG (2018). A review of semivolatile organic compounds (SVOCs) in the indoor environment: occurrence in consumer products, indoor air and dust. Chemosphere 201, 466-482.

82. Ma Y and Harrad S (2015). Spatiotemporal analysis and human exposure assessment on polycyclic aromatic hydrocarbons in indoor air, settled house dust, and diet: a review. Environ Int 84, 7-16.

83. Mabilia R Cecinato, A, Tomasi ScianòM.C, Di Palo V, Possanzini M (2004). Characterization of polycyclic aromatic hydrocarbons and carbonyl compounds in diesel exhaust emissions. Annali di 
Chimica 94, 733-740.

84. MacKay D and Callcott D (1998). Partitioning and physical chemical properties of PAHs. In: PAH and Related Compounds Chemistry. Neilson, A (Ed), Springer-Verlag, Berlin, pp. 325-346.

85. Maechler M, Rousseeuw P, Struyf A, Hubert M, Hornik K (2019). Cluster: Cluster Analysis basics and extensions. R package version 2.1.0, 2019.

86. Medeiros PM and Simoneit BRT (2008). Source profiles of organic compounds emitted upon combustion of green vegetation from temperate climate forests. Environ Sci Technol 42, 8310-8316.

87. Mininni G, Sbrilli A, Guerriero E, Rotatori M (2004). Dioxins and furans formation in pilot incineration tests of sewage sludge spiked with organic chlorine. Chemosphere 54, 1337-1350.

88. Molnar C (2019). Interpretable Machine Learning: A Guide for Making Black Box Models Explainable. URL https://christophm. github. io/interpretable-ml-book.

89. Mostert MMR, Ayoko GA, Kokot S (2010). Application of chemometrics to analysis of soil pollutants. TrAC Trends Anal Chem 29, 430-445.

90. Ngo TH, Tsou HH, Chen YF, Chen YW, Chi KH (2018). Sources identification of PCDD/Fs in soil and atmospheric deposition in Taiwan. Chemosphere 208, 374-381.

91. Ngo TH, Yang YH, Chen YC, Pan WC, Chi KH (2020). Continuous nationwide atmospheric PCDD/F monitoring network in Taiwan (2006-2016): Variation in concentrations and apportionment of emission sources. Chemosphere 255, 126979.

92. Nieder R, Benbi DK, Reichl FX (2018). Soil-borne particles and their impact on environment and human health. In: Soil Components and Human Health, Springer, Dordrecht, pp. 99-177.

93. Oliveira C, Pio C, Alves C, Evtyugina M, Santo P, Goncalves V, Nunes T, Silvestre AJD, Palmgren F, Walin P, Harrad S (2007). Seasonal distribution of polar organic compounds in the urban atmosphere of two large cities from the North and South of Europe. Atmos Environ 41, 5555-5570.

94. Oliveira M., Slezakova K, Delerue-Matos C, do Carmo Pereira M, Morais S (2016). Assessment of polycyclic aromatic hydrocarbons in indoor and outdoor air of preschool environments (3-5 years old children). Environ Pollut 208, 382-394.

95. Omar NYMJ, Bin Abas MR, Rahman NA, Tahir NM, Rushdi Al, Simoneit BRT (2007). Levels and distributions of organic source tracers in air and roadside dust particles of Kuala Lumpur, Malaysia. Environ Geol 52, 1485-1500.

96. Oros DR and Simoneit BRT (2001a). Identification and emission factors of molecular tracers in organic aerosols from biomass burning. Part 1. Temperate climate conifers. Appl Geochem 16, 15131544.

97. Oros DR and Simoneit BRT (2001b). Identification and emission factors of molecular tracers in organic aerosols from biomass burning. Part 2. Deciduous trees. Appl Geochem 16, 1545-1565.

98. Oros DR, Mazurek MA, Baham JE, Simoneit BRT (2002). Organic tracers from wild fire residues in soil and rain/river washout. Water Air Soil Pollut 137, 203-233. 
99. Paolini V, Guerriero E, Bacaloni A, Rotatori M, Benedetti P, Mosca S (2015). Simultaneous sampling of vapor and particle-phase carcinogenic polycyclic aromatic hydrocarbons on functionalized glass fiber filters. J Aerosol Air Qual Res 16, 175-183.

100. Percy Z, La Guardia MJ, Xu Y, Hale RC, Dietrich KN, Lanphear BP, Yolton K, Vuong AM, Cecil KM, Braun JM, Xie C, Chen A (2020). Concentrations and loadings of organophosphate and replacement brominated flame retardants in house dust from the home study during the PBDE phase-out. Chemosphere 239, 124701.

101. Perraudin E, Budzinski H, Villenave E (2007). Kinetic study of the reactions of ozone with polycyclic aromatic hydrocarbons adsorbed on atmospheric model particles. J Atmos Chem 56, 57-82.

102. Perrino C, Tofful L, Dalla Torre S., Sargolini T, Canepari S (2019). Biomass burning contribution to PM10 concentration in Rome (Italy): Seasonal, daily and two-hourly variations. Chemosphere 222, 839-848.

103. Perrone MG, Carbone C, Faedo D, Ferrero L, Maggioni A, Sangiorgi E, Bolzacchini E (2014). Exhaust emissions of polycyclic aromatic hydrocarbons, $n$ - alkanes and phenols from vehicles coming within different European classes. Atmos Environ 82, 391- 400.

104. Petracchini F, Romagnoli P, Paciucci L, Vichi F, Imperiali A, Paolini V, Liotta F, Cecinato A (2017). Influence of transport from urban sources and domestic biomass combustion on the air quality of a mountain area. Environ Sci Pollut Res 24, 4741-4754.

105. Pio CA, Alves CA, Duarte AC (2001). Identification, abundance and origin of atmospheric organic particulate matter in a Portuguese rural area. Atmos Environ 35, 1365-1375.

106. Pitts JN Jr, Sweetman JA, Zielinska B, Winer AM, Atkinson R (1985). Determination of 2nitrofluoranthene and 2-nitropyrene in ambient particulate organic matter: Evidence for atmospheric reactions. Atmos Environ 10, 1601-1608.

107. Pomata D, Di Filippo P, Riccard, C, Buiarelli F, Gallo V (2014). Determination of non-certified levoglucosan, sugar polyols and ergosterol in NIST Standard Reference Material 1649a. Atmos Environ 84, 332-338.

108. Praveena SM, The SW, Rajendran RK, Kannan N, LinC.C, Abdullah R Kumar, S (2018). Recent updates on phthalate exposure and human health: a special focus on liver toxicity and stem cell regeneration. Environ Sci Pollut Res 25, 11333-11342.

109. Rabhi L, Lemou A, Cecinato A, Balducci C, Cherifı N, Ladji R, Yassaa N (2018). Polycyclic aromatic hydrocarbons, phthalates, parabens and other environmental contaminants in dust and suspended particulates of Algiers, Algeria. Environ Sci Pollu. Res 25, 24253-24265.

110. Ravindra K, Sokhi R, Van Grieken R (2008). Atmospheric polycyclic aromatic hydrocarbons: source attribution, emission factors and regulation. Atmos Environ 42, 2895-2921.

111. Ren G, Yan X, M, Y, Qiao L, Chen Z, Xin Y, Zhou M, Shi Y, Zheng K, Zhu S, Huang C, Li L (2020). Characteristics and source apportionment of $\mathrm{PM}_{2.5}$-bound saccharides and carboxylic acids in Central Shanghai, China. Atmos Res 237, 104817. 
112. Romagnoli P, Balducci C, Perilli M, Gherardi M, Gordiani A, Gariazzo C, Gatto MP, Cecinato A (2014). Indoor PAHs at schools, homes and offices in Rome, Italy. Atmos Environ 92, 51-59.

113. Sangiorgi G, Ferrero L, Ferrini BS, Porto CL, Perrone MG, Zangrando R, Gambaro A, Lazzati Z, Bolzacchini E (2013). Indoor airborne particle sources and semi-volatile partitioning effect of outdoor fine PM in offices. Atmos Environ 65, 205-214.

114. Shen G, Tao S, Wei S, Zhang Y, Wang R, Wang B, Li W Shen, H, Huang Y, Yang Y, Wang W, Wang X, Simonich SLM (2012). Retene emission from residential solid fuels in China and evaluation of retene as a unique marker for soft wood combustion. Environ Sci Technol 46, 4666-4672.

115. Sifakis S, Androutsopoulos VP, Tsatsakis AM, Spandidos DA (2017). Human exposure to endocrine disrupting chemicals: effects on the male and female reproductive systems. Environ Toxicol Pharmacol51, 56-70.

116. Simoneit BR (1984). Organic matter of the troposphere-III - Characterization and sources of petroleum and pyrogenic residues in aerosols over the western United States. Atmos Environ 18, 5167.

117. Simoneit BRT and Mazurek MA (1982). Organic matter of the troposphere - II - Natural background of biogenic lipid matter in aerosol over the rural Western United States. Atmos Environ 16, 2139-2159.

118. Simoneit BRT (2002). Biomass burning - a review of organic tracers for smoke from incomplete combustion. Applied Geochem 17, 129-162.

119. Sofowote UM, Allan LM, McCarry BE (2010). Evaluation of PAH diagnostic ratios as source apportionment tools for air particulates collected in an urban-industrial environment. J Environ Monit $12,417-422$.

120. Sofowote UM, HealyR.M, Su Y, Debosz J, Noble M, Munoz S, Jeong CH, Wang JM, Hilker N, Evans JY, Brook JR, Lu G, Hopke PK (2020). Sources, variability and parameterizations of intra-city factors obtained from dispersion-normalized multi-time resolution factor analyses of PM2.5 in an urban environment. Sci Total Environ, https://doi.org/10.1016/j.scitotenv.2020.143225.

121. Steinemann A (2018). Fragranced consumer products: sources of emissions, exposures, and health effects in the UK. Air Qual Atmos Health 11, 253-258.

122. Subedi B, Sullivan KD, Dhungan B (2017). Phthalate and non-phthalate plasticizers in indoor dust from childcare facilities, salons, and homes across the USA. Environ Pollut 230, 701-708.

123. Tobiszewski M, Namiesnik J (2012). PAH diagnostic ratios for the identification of pollution emission sources. Environ Pollut 162, 110-119.

124. Tong KY, Karasek FW (1984). Quantitation of polycyclic aromatic hydrocarbons in diesel exhaust particulate matter by high-performance liquid chromatography fractionation and high-resolution gas chromatography. Anal Chem 56, 2129-2134.

125. Tran TM, Kannan K (2015). Occurrence of phthalate diesters in particulate and vapor phases in indoor air and implications for human exposure in Albany, New York, USA. Arch Environ Contam Toxicol 68, 489-499. 
126. Udayakumar GP, Muthusamy S, Selvaganesh B, Sivarajasekar N, Rambabu K, Banat F, Sivamani S, Sivakumar N, Hosseini-Bandegharaei A, Show PL (2021). Biopolymers and composites: Properties, characterization and their applications in food, medical and pharmaceutical industries. J Environ Chem Engineer 9, 105332.

127. USEPA (1993). Provisional Guidance for the Quantitative Risk Assessment of Polycyclic Aromatic Hydrocarbons. Office of Research and Development, Washington, D.C. 1993. EPA/600/R-93/089.

128. Vaz S Jr (2018). The Main Environmental Matrices: Air, Soil, and Water. In: Analytical Chemistry Applied to Emerging Pollutants, Springer International Publishing AG, part of Springer Nature, Chapter 4, pp. 79-101.

129. Ventrice P, Ventrice D, Russo E, De Sarro G (2013). Phthalates: European regulation, chemistry, pharmacokinetic and related toxicity. Environ Toxicol Pharmacol 36, 88-96.

130. Wang Y, Fang X, Zhang T, Li Y, Wu Y, He D, Wang Y (2010). Predominance of even carbon-numbered n-alkanes from lacustrine sediments in Linxia Basin, NE Tibetan Plateau: Implications for climate change. Applied Geochem 25, 1478-1486.

131. Wise SA, Benner BA, Byrd GD, Chesler SN, Rebbert RE, Schantz MM (1988). Determination of polycyclic aromatic hydrocarbons in a coal tar standard reference material. Anal Chem $60,9,887-$ 894

132. Wong F, Robson M, Melymuk L, Shunthirasingham C, Alexandrou N, Shoeib M, Luk E, Helm P, Diamond ML, Hung H (2019). Urban sources of synthetic musk compounds to the environment. Environ Sc. Processes Impacts 21, 74-88.

133. Xiao H, Li M, Wang W, You B, Liu X, Yang Z, Liu J, Chen Q, Uwiringiyimana M (2019). Identification, distribution and geochemical significance of four rearranged hopane series in crude oil. Org Geochem 138, 102939.

134. Yassaa N, Meklati BY, Cecinato A, Marino F (2001). Particulate $n$-alkanes, n-alkanoic acids and polycyclic aromatic hydrocarbons in the atmosphere of Algiers City Area. Atmos Environ 35, $1843-$ 1851.

135. Yury B, Zhang Z, Ding Y, Zheng Z, Wu B, Gao P, Jia J, Lin N, Feng Y (2018). Distribution, inhalation and health risk of $\mathrm{PM}_{2.5}$ related PAHs in indoor environments. Ecotoxicol Environ Safety 164, 409415.

136. Zhao Y, Hu M, Slanina S, Zhang Y (2007). Chemical compositions of fine particulate organic matter emitted from Chinese cooking. Environ Sci Technol 41, 99-105.

137. Zhu Q, Jia J, Zhang K, Zhang H, Liao C, Jiang G (2019). Phthalate esters in indoor dust from several regions, China and their implications for human exposure. Sci Total Environ 2019, 652, 1187-1194.

138. Zielinska B, Sagebiel J, McDonald JD, Whitney K, Lawson DR (2004). Emission rates and comparative chemical composition from selected in-use diesel and gasoline-fueled vehicles. J Air Waste Management Assoc 54, 1138-1150.

\section{Tables}


Table 1. Indexes describing the n-alkane percent distributions, typical of various emission types.

\begin{tabular}{|lllllll|}
\hline $\begin{array}{l}\text { index / } \\
\text { source }\end{array}$ & petroleum & algae & microorganisms & $\begin{array}{l}\text { high } \\
\text { trees }\end{array}$ & vegetation & anthropogenic \\
\hline $\mathrm{C}_{\text {max }}$ & $\mathrm{C}_{16} \sim \mathrm{C}_{21}$ & $\begin{array}{l}\mathrm{C}_{17}, \mathrm{C}_{19}, \\
\mathrm{C}_{21}, \mathrm{C}_{23}\end{array}$ & $\mathrm{C}_{16}, \mathrm{C}_{18}, \mathrm{C}_{20}$ & $\begin{array}{l}\mathrm{C}_{29}, \\
\mathrm{C}_{31}, \mathrm{C}_{33}\end{array}$ & $\begin{array}{l}\mathrm{C}_{25}, \mathrm{C}_{27}, \\
\mathrm{C}_{29}\end{array}$ & $\mathrm{C}_{16} \sim \mathrm{C}_{23}$ \\
$\mathrm{CPI}_{25}$ & $0.7-1.3$ & & $>1$ & $>10$ & $>3$ & $0.8-1.3$ \\
$\mathrm{CPI}_{11}$ & $0.8-1.2$ & $>1.0$ & $<1.0$ & & & \\
$\mathrm{NW}$ & $\sim 0$ & & & $>75$ & $>75$ & $\sim 0-30$ \\
\hline
\end{tabular}

Symbols: $A T S R=$ tobacco smoking index [see formula (3) in the text]; AICR = mean of anteiso/iso-alkane concentrations [see formula (4) in the text]; $\mathrm{SH}=$ tobacco smoker house; $\mathrm{NSH}=$ no tobacco smoker house.

Table 2. Rates of the principal PAH concentration ratios currently used as diagnostic tools to draw insights about the nature of source. References: Kavouras et al 2001, Tobiszewski and Namiesnik 2012, Cecinato et al 2014).

\begin{tabular}{|c|c|c|c|c|c|c|}
\hline source & type & FA/PY & $\mathrm{BaA} / \mathrm{CH}$ & IP/BPE & $\mathrm{BaP} / \mathrm{BPE}$ & $\mathrm{BaP} / \mathrm{BeP}$ \\
\hline \multirow[t]{3}{*}{ vehicles } & mixed & 0.60 & & & 0.55 & \\
\hline & gasoline & 0.54 & $0.8-1.3$ & $0.20-0.35$ & 0.35 & 0.95 \\
\hline & diesel & $0.8-1.1$ & 0.38 & $0.65-1.1$ & $0.8-1.1$ & 0.50 \\
\hline \multirow[t]{5}{*}{ domestic heating } & coal & & 0.65 & $0.9-1.3$ & 1.57 & \\
\hline & wood, pine & 0.78 & 0.64 & $1.1-1.6$ & 1.94 & 2.1 \\
\hline & wood, oak & 0.75 & 0.70 & $1.2-1.6$ & 1.77 & 1.77 \\
\hline & synthesis fuel & 1.19 & 0.78 & 1.1 & 1.91 & \\
\hline & heavy oil & 0.83 & 1.01 & 1.6 & 0.81 & 0.52 \\
\hline \multirow[t]{2}{*}{ steel plant } & coke & & 0.65 & $0.9-1.3$ & 1.57 & \\
\hline & power (coke) & 0.66 & 0.56 & 2.0 & 0.88 & 2.57 \\
\hline tobacco smoke & particulate & 0.96 & 1.3 & 0.18 & 0.23 & 0.38 \\
\hline \multirow[t]{2}{*}{ waste fumes } & landfill & 1.3 & 0.84 & 0.76 & 0.70 & 0.55 \\
\hline & incinerator & $\approx 17$ & 0.71 & 0.92 & $\sim 0.12$ & 0.01 \\
\hline
\end{tabular}


Table 3. ATSR and AICR index rates of airborne particulates (PM) and settled dust collected in Algeria and Italy. The number of locations investigated in each group has reported between parentheses. Site types: Lazio, urban and rural; Italy and Algeria, urban. Symbols: $\mathrm{SH}=$ frequent smoker home, $\mathrm{NSH}=$ no smoker home.

\begin{tabular}{|c|c|c|c|c|c|c|}
\hline \multirow{4}{*}{$\begin{array}{l}\text { PM, } \\
\text { outdoor }\end{array}$} & sites & Lazio region & Italy & Italy & SH, Italy & Algeria \\
\hline & year time & summer (10) & summer (10) & winter (10) & spring (8) & summer (4) \\
\hline & ATSR & $0.11 \pm 0.05$ & $0.24 \pm 0.07$ & $0.24 \pm 0.08$ & $0.54 \pm 0.12$ & $0.12 \pm 0.02$ \\
\hline & AICR & $1.50 \pm 0.46$ & $1.54 \pm 0.28$ & $1.70 \pm 0.35$ & $3.56 \pm 0.50$ & $1.35 \pm 0.15$ \\
\hline \multirow{4}{*}{$\begin{array}{l}\text { PM, } \\
\text { indoor }\end{array}$} & sites & SH, Italy & SH, Italy & school, Italy & & \\
\hline & year time & spring (19) & winter (16) & winter (16) & & \\
\hline & ATSR & $1.16 \pm 0.05$ & $1.15 \pm 0.00$ & $0.30 \pm 0.04$ & & \\
\hline & AICR & $5.22 \pm 0.08$ & $4.48 \pm 0.20$ & $1.85 \pm 0.25$ & & \\
\hline \multirow{4}{*}{$\begin{array}{l}\text { dust, } \\
\text { indoor }\end{array}$} & sites & SH, Italy & $\mathrm{NSH}$, Italy & & & \\
\hline & year time & spring (19) & summer (14) & & & \\
\hline & ATSR & $0.27 \pm 0.09$ & $0.10 \pm 0.03$ & & & \\
\hline & AICR & $2.00 \pm 0.95$ & $1.08 \pm 0.10$ & & & \\
\hline
\end{tabular}

\section{Supplementary}

Supplementary figure is not available with this version.

\section{Figures}




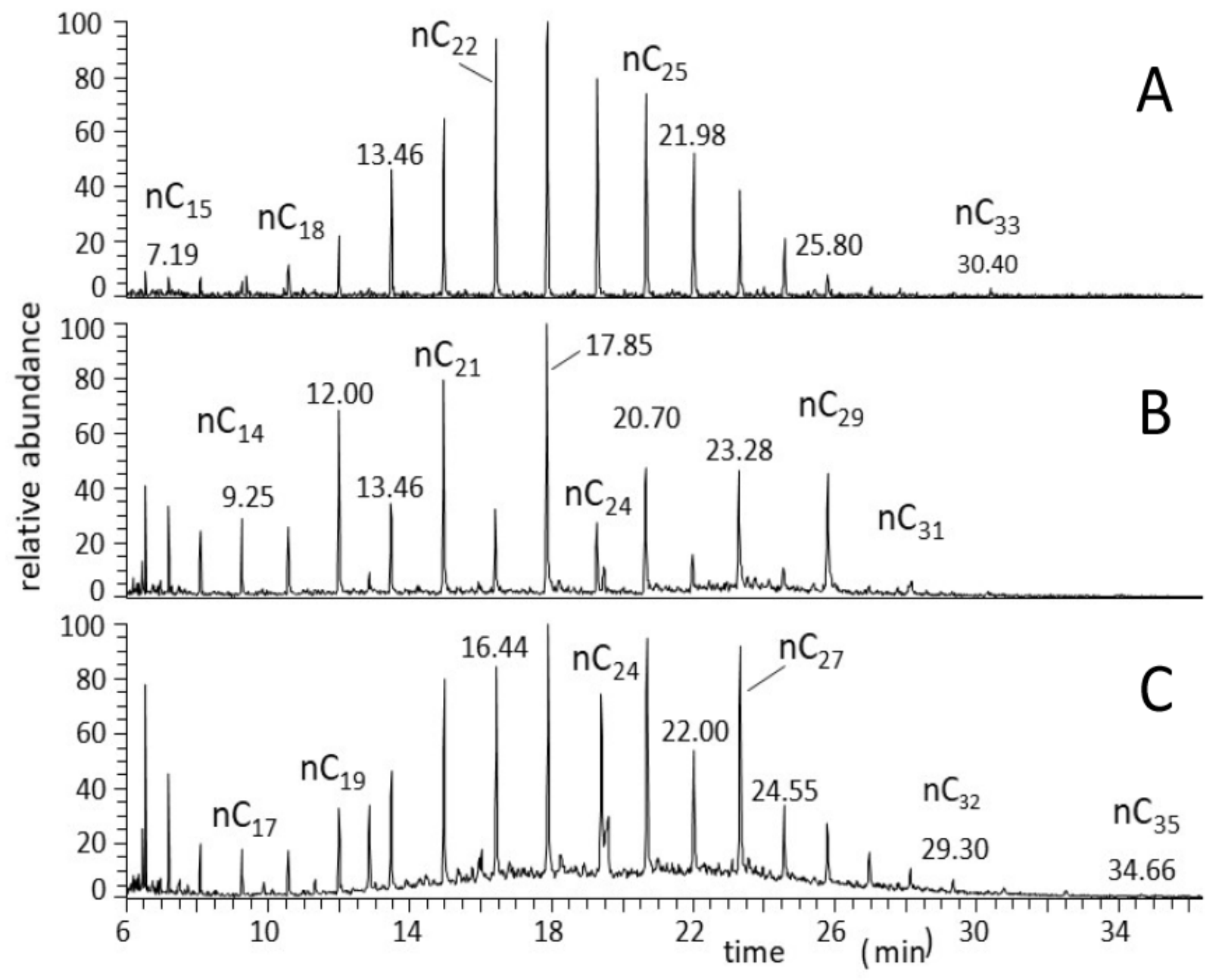

Figure 1

GC-MS profiles of the non-polar fraction $(\mathrm{m} / \mathrm{z}=85)$ of airborne particulates collected at four sites variously influenced by emission sources. A) road traffic site; B) rural region; C) urban location (city garden). Symbols: $\mathrm{nCi}$ indicates the $\mathrm{n}$-alkane with carbon number equal to $\mathrm{i}$. 


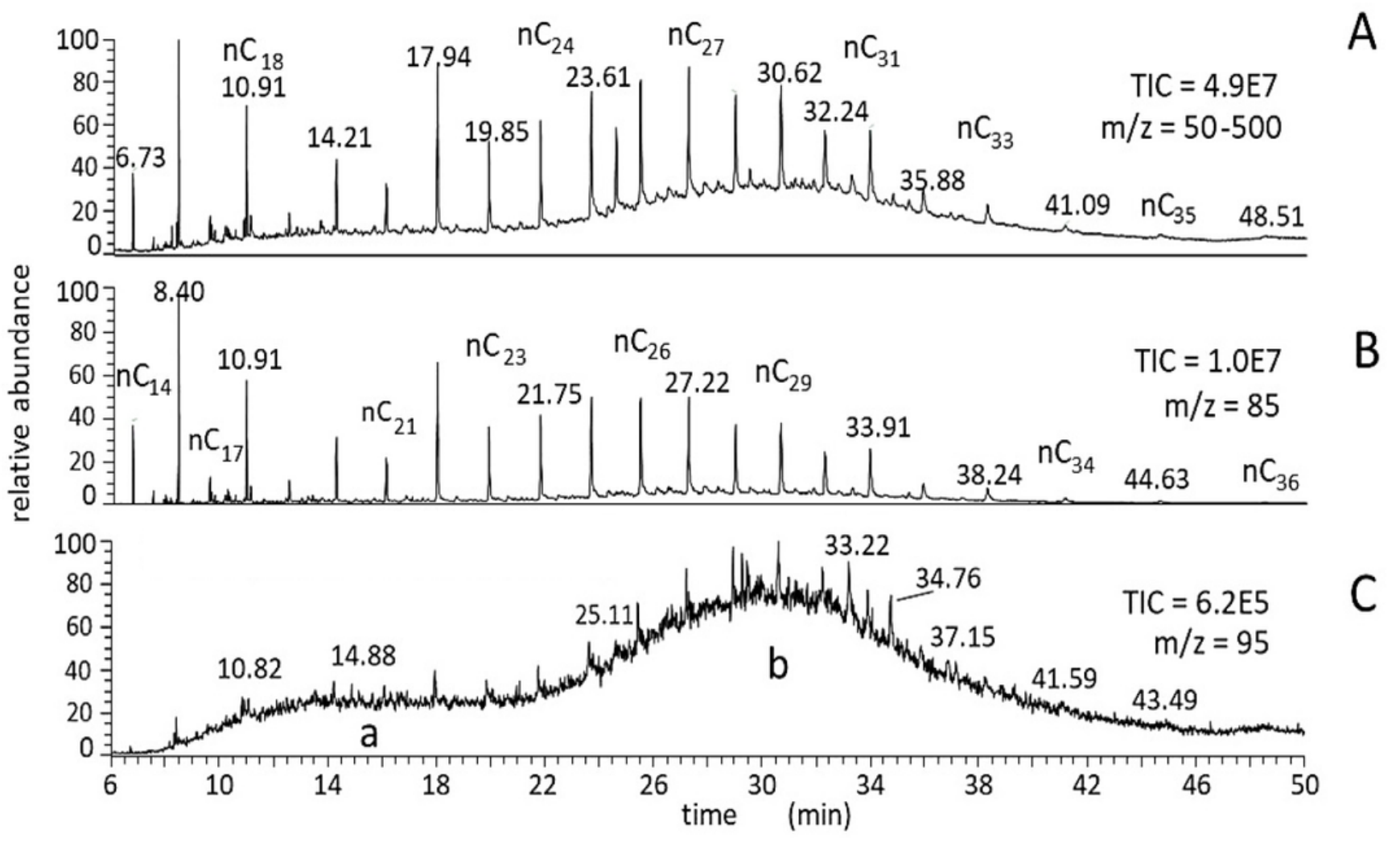

Figure 2

GC-MS profile of the non-polar fraction of diesel exhaust. A) total ion current signal; B) ion trace corresponding to $\mathrm{m} / \mathrm{z}=85$ (labeling $\mathrm{n}$-alkanes); $\mathrm{C}$ ) $\mathrm{m} / \mathrm{z}=95$ ion trace (branched alkanes). Both $\mathrm{a}$ and $\mathrm{b}$ humps occur in the UCM. Symbols: $\mathrm{nCi}$ indicates the $\mathrm{n}$-alkane with carbon number equal to $\mathrm{i}$. 


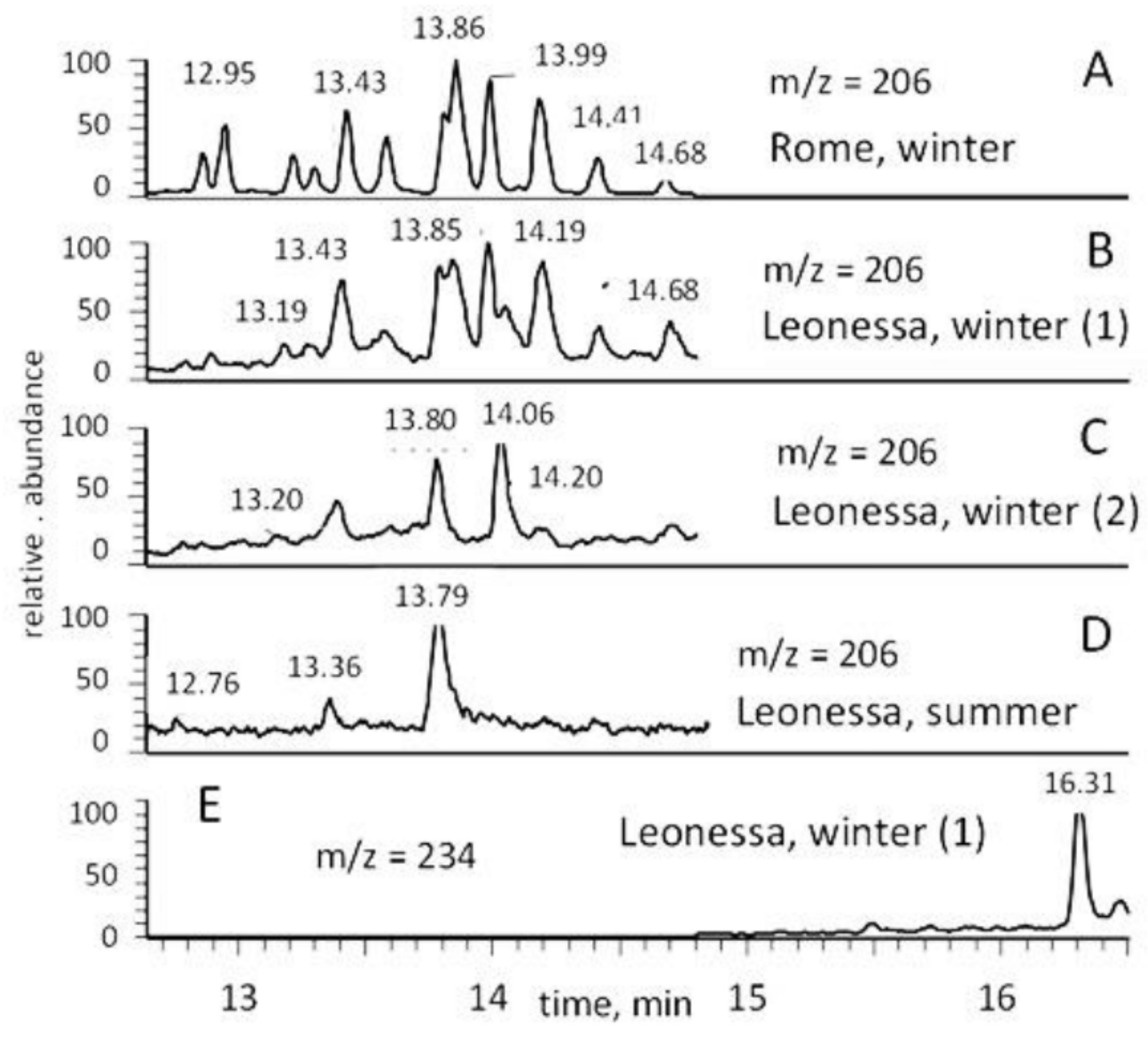

Figure 3

GC-MSD profiles of PAH compounds affecting the suspended particulates of Rome and Leonessa, Italy. A) Dimethyl/ethyl phenanthrenes in Rome downtown, winter season; B) Dimethyl/ethyl phenanthrenes in Leonessa, winter (sample 1); C) Dimethyl/ethyl phenanthrenes in Leonessa, winter (sample 2); D) Dimethyl/ethyl phenanthrenes in Leonessa, summer season; E) Retene in Leonessa, winter (sample 2). 


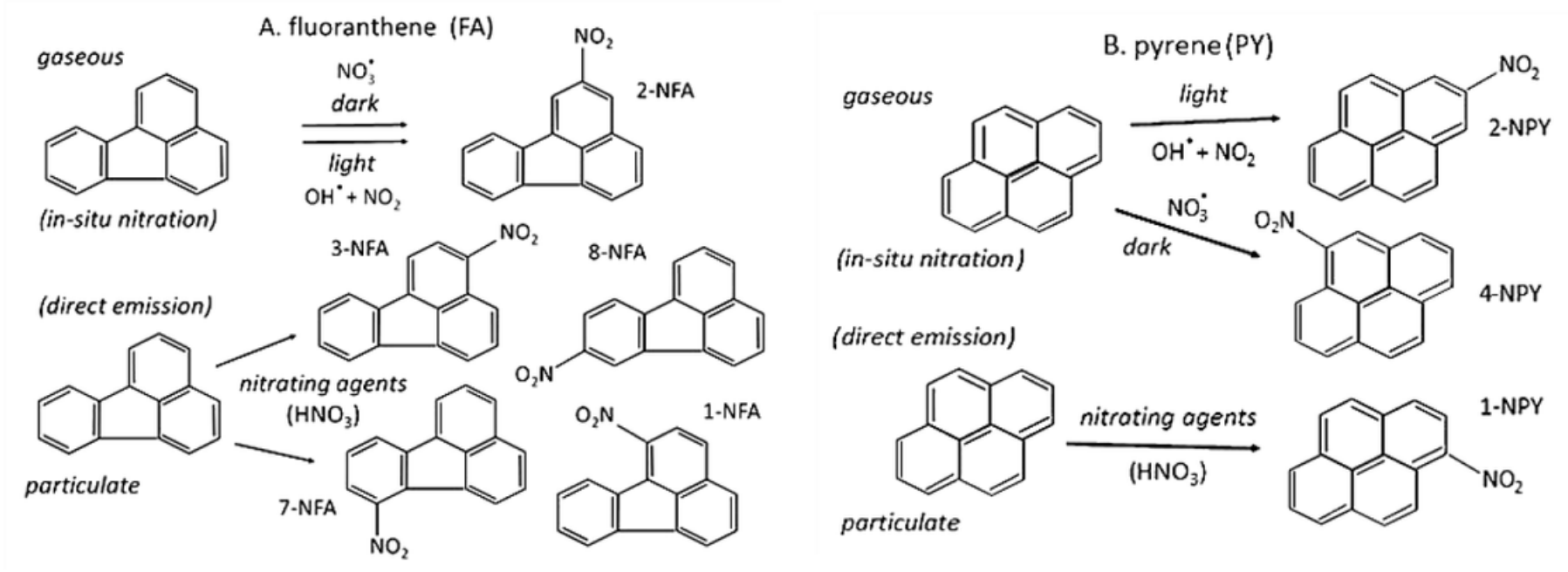

\section{Figure 4}

Ways of fluoranthene and pyrene nitration leading to formation of distinct nitro-substituted isomers affecting the atmosphere. A) fluoranthene; B) pyrene

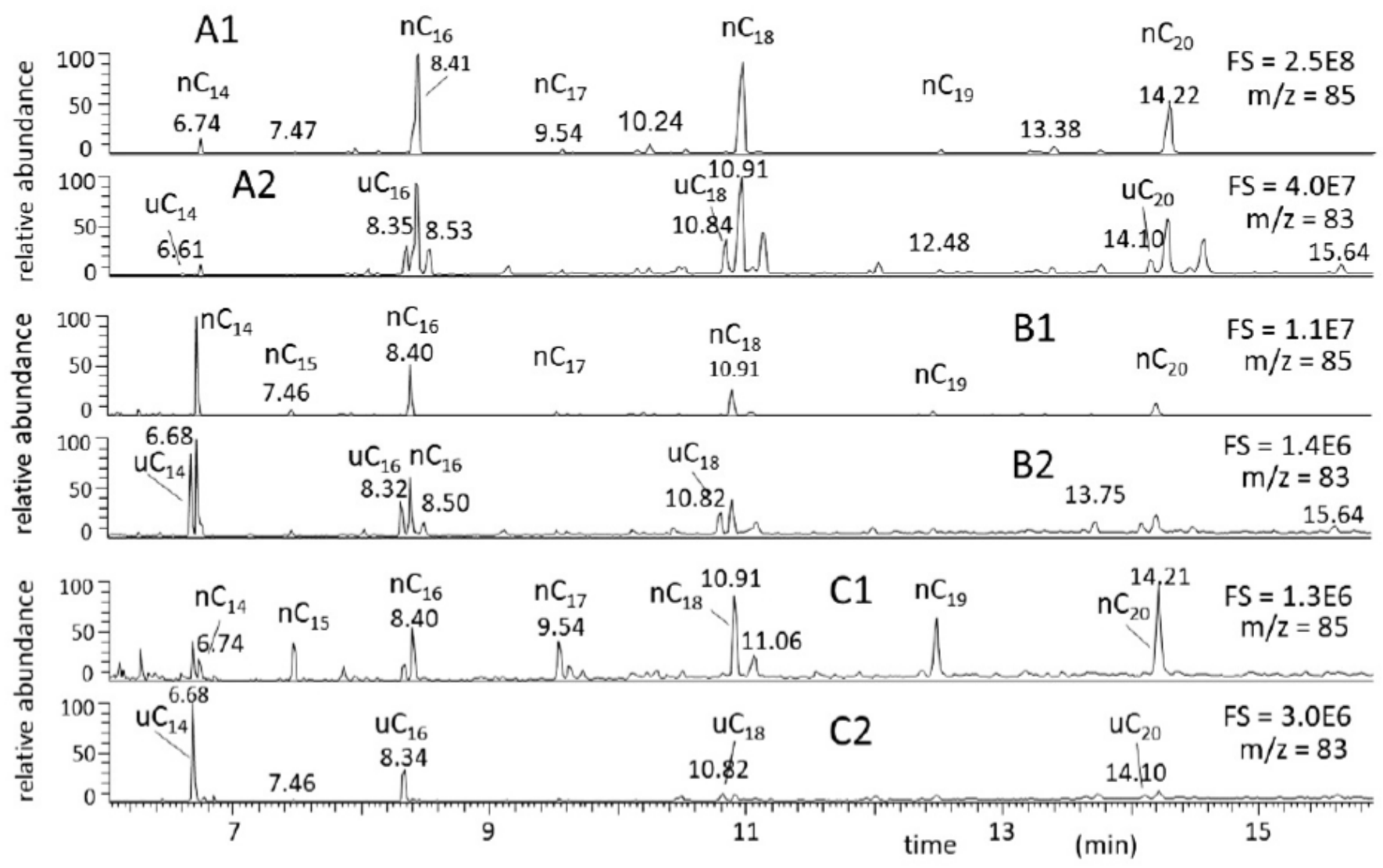


Figure 5

GC-MS chromatograms of airborne particulate extracts. A1) El Bey, Tunisia, m/z = 85 (n-alkanes); A2) El Bey, Tunisia, m/z = 83 (n-alkenes); B1) Tipaza, Algeria, m/z = 85 (n-alkanes); B2) Tipaza, Algeria, m/z = 83 (n-alkenes); C1) Reggio Calabria, Italy, m/z = 85 (n-alkanes); C2) Reggio Calabria, Italy, m/z = 83 (nalkenes).

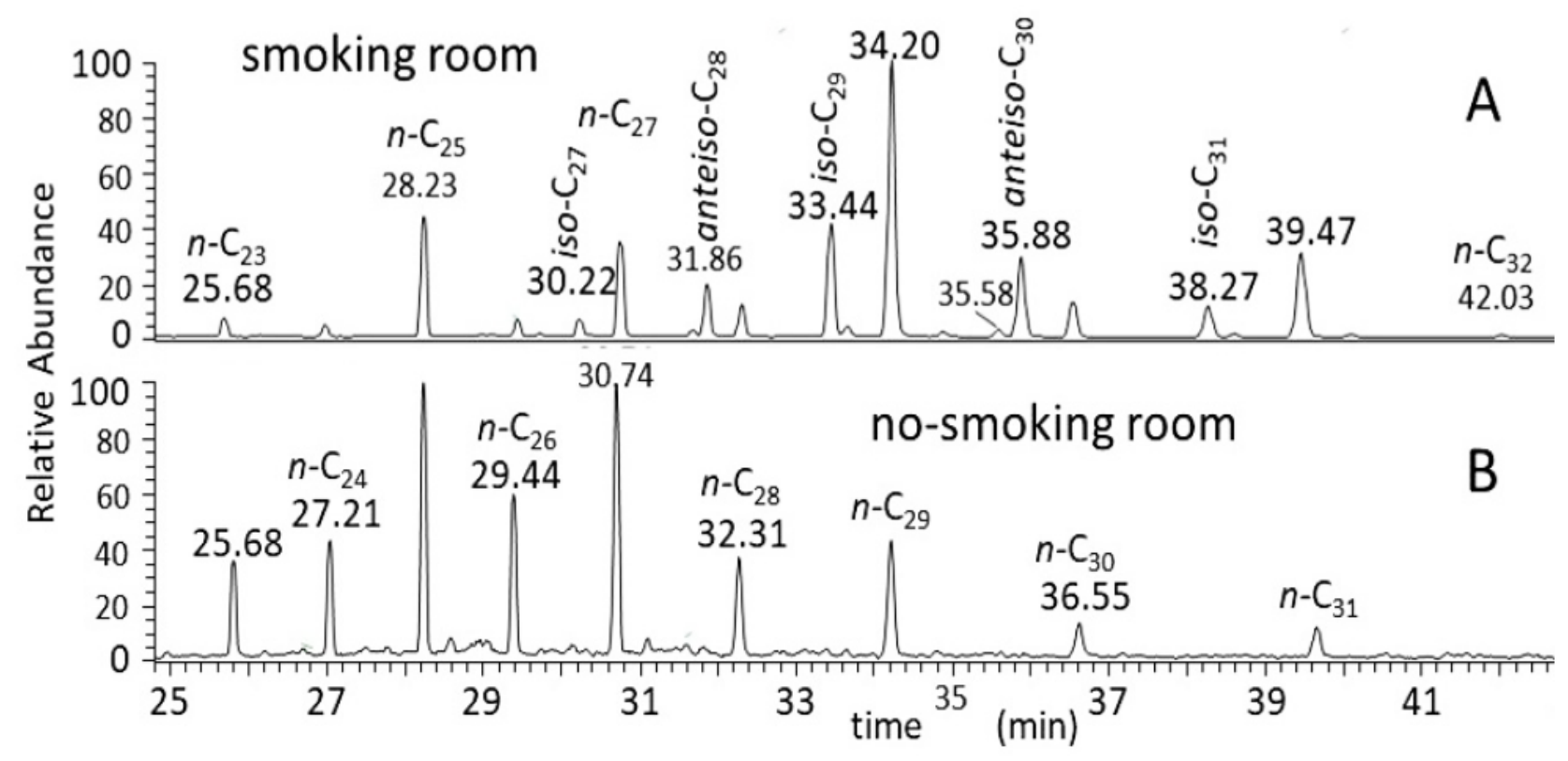

\section{Figure 6}

GC-MS profiles ( $\mathrm{m} / \mathrm{z}=85)$ of dusts collected in interiors. A) private house, frequent smoker dwelling; $B$ ) waiting room, public hospital. 